\title{
The Effect of Principal Leadership Behaviour and Work Culture Towards Work Discipline Elementary School Teachers on District Minahasa
}

\author{
Richie Gerungan Ahmad Paturusi Martinus Krowin \\ Magister Education Management Postgraduate Program \\ Manado State University, Indonesia
}

\begin{abstract}
This This study aims to obtain the results of analysis and clear interpretation of: (1) The positive influence of principals' leadership on the work discipline of elementary school teachers in Minahasa District. (2) The positive influence of work culture on the work discipline of elementary school teachers in Minahasa District. (3) The positive influence of the principal's leadership and work culture simultaneously (together) on the work discipline of elementary school teachers in Minahasa District. Sampling techniques using simple random sampling and data testing techniques used validity test by calculating between scores in each statement with a total score, using the Pearson Product Moment formula and reliability testing using the Cronbach Alpha formula. Testing the analysis requirements used the normality test and linearity test. To prove the research hypothesis on each independent variable with the dependent variable using simple regression analysis. Whereas for the effect of jointly between independent variables and dependent variables using multiple regression analysis. The results of the analysis show that: (1) there is a positive influence on Principal Leadership and Work Discipline, (2) there is a positive influence on the work culture and work discipline, (3) there is a positive influence of Principal Leadership and Work Culture simultaneously (together) with Work Discipline. Based on the results of the study it can be concluded that the work discipline of elementary school teachers in Minahasa Regency can be improved through improving the quality of the work culture and the function of leadership behavior.
\end{abstract}

Keywords: Principal Leadership Behavior, Work Culture, Work Discipline.

DOI: $10.7176 / \mathrm{JEP} / 10-21-02$

Publication date:July $31^{\text {st }} 2019$

\section{Introduction}

The world of education faces severe challenges, especially in producing quality human resources with high competitiveness in the global labor market. Improving the quality of education is an integral part of the process of developing human resources. Without quality human resources, a nation will not be able to compete in the era of globalization that is full of competition. Increasing human resources is one of the most important tasks and responsibilities of the government to always strive for. One effort to improve the quality of human resources is education. There is no one nation or country that can advance without first advancing the world of education.

Work discipline must begin to be applied at the beginning of the prescription of an activity until the implementation of activities, so that in carrying out the task will be directed and not experiencing obstacles. Work discipline must start from a leader to executors in the field. If one activity is not disciplined, it will hamper the other part. Thus it can be said that if we want to succeed well, then start applying work discipline well too.

Thus it can be interpreted that work discipline is one of the main keys to success. Many failures caused by being undisciplined. Schools as educational institutions are tasked with organizing the educational process and teaching and learning processes in an effort to educate the life of the nation. In this case the principal is someone who is given the task of leading the school, the principal is responsible for achieving school goals. The principal is expected to be a leader and innovator in the school. Therefore, the leadership quality of the principal is significant for the success of the school. Principals need to have the ability to empower all existing human resources (HR) to achieve school goals. Especially with regard to teacher principals must have the ability to improve teacher performance, through empowering human resources (teachers).

Principal leadership is an effort of the principal to influence, encourage, guide, direct and move teachers, staff, students, parents of students and other personal related to work together in achieving the goals set. The role of the principal as a leader is mainly emphasized on how the principal is able to make other people work in order to achieve the goals set by the school. So, the leadership of the principal is an important factor in creating a teacher work culture that will affect the performance of teachers to achieve the quality of education in each school.The success of a job, rooted in the values that are owned and behaviors that become habits. These values originate from customs, religion, norms and rules that become his beliefs which are habits in work behavior or organization. A habit is called culture. Because culture is associated with quality or quality of work, it is called work culture.

The definition of culture is expressed by many experts such as Koentjaraningrat (2007), namely; "Culture is the whole human being from the behavior and results of regular behavior by the behavior that must be obtained 
by learning and everything is arranged in the life of the community". Work culture is a group of behavioral patterns that are inherent in all individuals within an organization. Building culture also means enhancing and maintaining positive sides, and trying to familiarize (habituating the process) certain behavioral patterns in order to create a better new form.

Mulyasa (2011) suggests that the influence of education can be seen and felt directly in the development and life of society, group life, and the lives of every individual. Education deals directly with the formation of people. Education determines the human model that will be produced. From this explanation, it can be seen that in the process of improving the quality of education, one of its efforts is to improve the educator's human resource capacity in this case the teacher. Without the optimal role of the teacher any improvement efforts made to improve the quality of education will not provide a significant contribution without being supported by professional and quality teachers, therefore the teacher is the most influential component in creating quality education processes and outcomes.

Based on the results of observations in a number of elementary schools in Minahasa District, there were several parties who declined their enthusiasm in teaching, feeling bored, and bored with work. Demonstrate a work culture that does not favor the teacher's work discipline. School performance is determined by the atmosphere or work environment at the school. The conduciveness of the work culture of a school influences the attitudes and actions of the entire school community, especially in achieving student academic achievement. To improve the role of teachers in the teaching and learning process and student learning outcomes, the teacher is expected to be able to create an effective learning environment and will be able to manage the classroom. The teacher is a professional educator with the main task of educating and evaluating students in early childhood education in formal education, basic education and secondary education.

Thus it can be interpreted that work discipline is one of the main keys to success. Many failures caused by being undisciplined. Work discipline must begin to be applied at the beginning of the prescription of an activity until the implementation of activities, so that in carrying out the task will be directed and not experiencing obstacles. Work discipline must start from a leader to executors in the field. If one activity is not disciplined, it will hamper the other part. Thus it can be said that if we want to succeed well, then start applying work discipline well too.

This study aims to obtain clear results of analysis and interpretation of:

a. Positive influence of principals' leadership on the work discipline of elementary school teachers in Minahasa

District.

b. The positive influence of work culture on the work discipline of elementary school teachers in Minahasa District. c. The positive influence of the principal's leadership and work culture simultaneously (together) on the work discipline of elementary school teachers in Minahasa District.

\section{Literature review}

\subsection{Teacher Work Discipline}

Discipline is very important for the teacher. Therefore, discipline must be pursued continuously and consistently so that it can have a constructive and progressive spectrum in various aspects of life both for themselves and those around them. The teacher must be aware that high discipline can provide maximum results. Conversely, undisciplined will bring failure, setback, backwardness, and destruction, and suffering. Discipline comes from the Latin discere which means learning. From this word the word discipulu arises in Latin which means teaching (Kambey, 1995). Furthermore, now the word discipline experiences the development of meaning in several senses. First, the discipline is defined as compliance with regulations or subject to supervision and control. Second, discipline as an exercise that aims to develop themselves in order to behave in an orderly manner. According to the Indonesian Language Dictionary, discipline is obedience to regulations.

The understanding of discipline according to Wagner and Holienbeck (2010) is as follows :"Discipline is performing a task with obedience and dedication. It can be expected only when a firm's manager and subordinates agree on the specific behaviors that subordinates will perform". " Discipline is doing or carrying out a task with obedience and dedication. Discipline can be obtained only when a company manager and subordinates agree to behave specifically that the subordinates / subordinates will carry out. So, the discipline does a job in accordance with what has become a mutual agreement between managers and workers in this case the principal with the teacher.

From the definition of Armstrong (2006), it is known that discipline is as follows: "The disciplinary policy should state that employees have the right to know what is expected of them and what could happen if they infringe the organizations rules. It would also make the point that, in handling disciplinary cases, the organization will treat employees in accordance with in the principles of natural justice." Discipline policy should state that employees have the right to know what is expected of them and what can happen if they violate / abandon organizational rules. It will also show that in handling disciplinary cases, the organization will treat employees who adhere to the principle of natural justice. In this sense it can be concluded that discipline should have become an understanding for employees, so that they know what must be done and what sanctions or laws they will receive if they conduct 
discipline.

Whereas specifically Kanfer at all (2008), defines the discipline as follows: "Discipline is a responsibility that rests squarely on the supervisor's shoulders, it cannot be passed on a higher supervisor sand should never be passed on to personnel or the Human Resources Departement. Some make the mistake of believing that discipline is only directed at the inefficient worker. All employees require constructive discipline. There are times when disciplinary action is essential with an outstanding employee."

\subsection{Principal Leadership.}

Leadership is an activity in guiding a group in such a way that it reaches the goals of the group. leadership is a process where the leader will give orders or influence, on the ability to take the initiative in social situations to create, design and organize actions to generate cooperation towards the achievement of goals. Robbins (1991), says that " leadership is the ability to influence a group towards achievement (goals). "This opinion views all members of the group / organization as a whole, so that leadership is given the ability to influence all members of the group / organization to be willing to carry out activities / work to achieve group / organizational goals. It was said again according to Stoner, Freeman and Gilbert Jr. (quoted by Kambey, 2010), defines managerial leadership as a process of directing and influencing activities related to the tasks of group members.

Terry and Rue (quoted by Kambey, 2010), argued that leadership can be seen as the ability of a person or leader, to influence the behavior of others according to their desires in certain circumstances. Whereas Koontz and Weihrich; 1988 (quoted by Kambey 2010), suggests leadership as an influence, art or process influences people so that they are voluntary and eager to try to achieve group goals. Similar to Ivancevich and Donnelly (quoted by Kambey 2010), explaining leadership as an attempt to use a type of influence is not coercive to motivate people to achieve certain goals.Although these definitions appear to vary, if you look deeper, the core of these definitions is that leadership is a process that influences a person's activities or activities of a group of people so that they are directed towards achieving the stated goals.

Some of the definitions of leadership give a clear picture of how important group members or organizations are in realizing organizational goals. The meaning of leadership is related to the members of the organization, among others in the form of giving orders, guiding, influencing work groups or other people, giving direction, cooperating, giving certain tasks or authority, to involving organizational members in decision making. Furthermore, according to Yulk (2002), leadership is as follows: "Leadership is the process of influencing others to understand and agree about what needs to be done and how it can be done effectively, and the process of facilitating individual and collective effort to accomplish the kotashared objectives".

Leadership is the process of influencing others to understand and agree on what is needed to be done and how it is done effectively, and a process to facilitate individuals and groups trying to achieve goals together.Leadership is the process of influencing others to understand and agree on what is needed to be done and how it is done effectively, and a process to facilitate individuals and groups trying to achieve goals together.Ginnett and Curphy (2010) in Leadership books say that, "Leadership as the process of influencing and organized groups toward accomplishing its goals". Leadership is a process of influencing and directing an organization to achieve its objectives. Leadership style, contains an understanding as a manifestation of behavior of a leader, which concerns his ability to lead. The embodiment usually forms a certain pattern or shape.

Mantja (2005) more concisely states that through principals' leadership behavior that refers to task-oriented behavior and subordinate-oriented behavior, will form attitudes related to how teachers behave in carrying out their daily work. The actions and leadership style of the principal influence the motivation to lead the teacher in carrying out leadership roles effectively. "A principal style and actions have great influence over teacher leaders' motivation for performing teacher leadership roles effectively" (Birky, Shelton and Headly 2006 quoted by Mantja, 2005). Principals who are more functioning as managers than teaching leaders have schools that are less successful than those who work closely with teachers in carrying out their duties. As for some forms of actions that can be taken by the principal as stated by Syafarudin (2005) "giving autonomy in learning, capacity building and increasing respect for the work of the teacher.

\subsection{Work Culture}

Etymologically the plural form of the word culture is culture originating from Sanskrit namely budhaya, and in large dictionaries of Indonesian Language defines culture is the mind of reason resulting from human activity and creator (mind) such as belief, art and customs, while using approach anthropology, that is, all human knowledge as social creatures used to understand the environment and its experience and guide its behavior.Culture in the opinion of Edward Burnett Tylor (quoted by Ndraha, 1997) includes culture and civilization, namely culture is a complex whole consisting of knowledge, beliefs, art, morals, laws, customs, and other abilities as well as habits acquired by someone as a member of society.

Komariah and Triatna (2006) conclude that culture is a view of life in the form of moral values, habits, works, experiences and traditions that take root in a society and influence the attitudes and behavior of every person in 
the community.From the various definitions, an understanding of culture can be obtained which will affect the level of knowledge and include systems of ideas or ideas contained in the human mind, so that in everyday life, culture is abstract. While the embodiment of culture are objects created by humans as cultured beings, in the form of behaviors and objects of a real nature, for example patterns of behavior, language, living equipment, social organizations, religion, art, etc., which all of which are shown to help humans carry out community life.

Triguno (2000) argues that work culture is a philosophy that is based on a view of life as values that are traits, habits and driving forces, entrenched in the life of a community group or organization, then reflected in attitude to behavior, belief, ideals opinions and actions that manifest as work or work.A work culture that describes the atmosphere and working relationships between fellow teachers, teachers and principals, teachers and other education staff and between their environmental services is a manifestation of a conducive environment. This atmosphere is needed by teachers and principals to carry out their work more effectively.

The work culture can be described through mutual support for friendship, intimacy and cooperation. Conditions that occur in the four dimensions of the school culture have the potential to improve teacher performance. Teacher's work culture is an assessment of activities in the work environment that are carried out through the teacher's perception of what is seen, felt and thought about in the work environment. Which can be seen from two angles, namely the physical environment conditions of work and environmental conditions of work. Based on several opinions above, it can be synthesized that work culture is a belief values, norms that are held together in a group or organization that will manifest in a behavior at work. Or in other words that work culture is a philosophy that is written into customs, habits, norms, behaviors, rules that can be a characteristic of an organization in carrying out its work. The picture of the research model can be seen in Figure 1

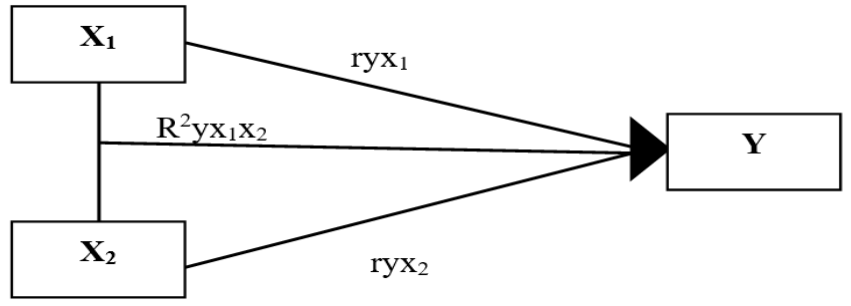

Figure 1. Research Model

Research hypothesis :

$\mathrm{X} 1=$ Principal's leadership

$\mathrm{X} 2=$ Work culture

$\mathrm{Y}=$ Work discipline

Based on the outlined framework, the research hypothesis can be formulated as follows:

1. There is a significant influence on the principal's leadership (X1) on work discipline (Y).

2. There is a significant influence on work culture (X2) on work discipline (Y).

3. There is a significant influence on principals' leadership (X1) and work culture (X2) together on work discipline (Y).

\section{Research Method}

This study will analyze and find out whether there is a relationship between the independent variables of the principal's leadership (X1) with the dependent variable (dependent variable) work discipline (Y), the independent variable of work culture (X2) with the dependent variable (dependent variable) work discipline (Y) and the relationship between independent variables (independent variable) leadership of the principal (X1) and work culture (X2) simultaneously (together) with the dependent variable (dependent variable) work discipline (Y).

The population and sample used as the unit of analysis in this study were elementary school (SD) teachers in the Minahasa, especially in Minahasa District. Affordable populations cover 12 Elementary Schools totaling 95 Teachers.From the total population of 95 people, using the Slovin formula obtained a total sample of 77 people. In order for each school to have a teacher representative, sampling is calculated proportionallyThe instrument that will be used in this study is a questionnaire or questionnaire as a measure to find out the status of respondents, namely elementary school teachers in Minahasa Regency. In this study, measurements were made on real situations seen in the opinions of respondents, felt and experienced by teachers related to the leadership of principals, work culture and work discipline of elementary school teachers in Minahasa, especially in Minahasa District subdistricts.

Data collection in this study was conducted by distributing questionnaires to teachers in 12 (twelve) primary schools in Minahasa District. Then the questionnaire is then used to collect data directly from the source, in this case the teacher. Questionnaires distributed as instruments are used as a measure of work discipline variables, principal leadership variables and work culture variables. Furthermore, the data is processed and reviewed for research purposes in completing this thesis. 
The data in this study will be analyzed using descriptive statistical techniques and inferential statistical techniques. Descriptive statistics are used to provide an overview of data from each research variable. The description is expressed by calculating the average score, median, mode, standard deviation, and s2 variance, and displaying the distribution of data in the form of frequency distribution tables and histograms (Taniredja, 2011).

Inferential statistics are used to test the research hypothesis through regression analysis techniques (Taniredja, 2011). Before testing hypotheses, the testing requirements for analysis are carried out, namely the data normality test and linearity test. For testing, use SPSS version 22 for Windows. The influence of one independent variable with one dependent variable was tested using simple linear regression analysis techniques. The influence that has been stated in the regression model is tested for its significance and linearity using the F-test on the ANOVA table (Nugroho, 2011). The strength of the relationship between one independent variable and one dependent variable is explained by calculating a simple correlation coefficient. The strength of the relationship between one independent variable and one dependent variable if the other independent variables are controlled is explained by calculating the partial correlation coefficient tested using the t-test (Nugroho, 2011).

\section{Result and Discussion}

4.1.Interpretation of Influence on Principal Leadership (X1) on Work Discipline (Y)

Descriptive results of work discipline variables $(\mathrm{Y})$ are explained by the number of cases $\mathrm{N}=77$ with an average of 128.45 and standard deviation $=16,386$. Descriptive results of leadership variables (X1) in the Descriptive Statistics table explain that there are a number of cases $N=77$ respondents; the mean (mean) is 126.65 and the standard deviation ( (standard deviation) $=15.239$

The results of the coefficient test, in this section constant $=78.143$ and $B$ value $=0.397$ and the price of tcount $=3.443$ and the significance level $=0.001$. From the coefficient table obtained the regression calculation equation is: $\ddot{\mathrm{Y}}=\mathrm{a}+\mathrm{bX} 1=78.143+0.397 \mathrm{X} 1$. The regression coefficient of 0.397 states that the better the headmaster's leadership is predicted to improve work discipline. Conversely, if the principal's leadership deteriorates, work discipline is also predicted to decline. So, this states the direction of predictions (linear). Information on the increase or decrease in the independent variable (X1) will result in an increase / decrease in the variable (Y).

Table 1

Coefisien Corelation $\mathrm{X}_{1}$ Toward $\mathrm{Y}$

\begin{tabular}{|c|c|c|c|c|}
\hline \multirow[b]{2}{*}{ Model } & Unstandardized Coefficients & Standardized Coefficients & \multirow{2}{*}{\multicolumn{2}{|c|}{ t Sig. }} \\
\hline & Std. Error & Beta & & \\
\hline 1 (Constant) & 14,717 & & 5,310 & 000 \\
\hline Perilaku Kep. X1 & 115 & ,369 & 3,443 & ,001 \\
\hline
\end{tabular}

From the coefficient table, the principal leadership variable and the work discipline of the Sig value are obtained. equal to 0.001 then compared with probability 0.05 it turns out that the probability value of 0.05 is greater than the probability value Sig. or [0.05>0.001], then Ho is rejected and Ha is accepted. It is evident that there is a significant influence on the principal's leadership towards work discipline.

The first hypothesis testing concludes that there is a significant positive relationship between principals' leadership on work discipline indicated by Fcount $=11,854>$ Ftable $=3,120$ at a significant level $\alpha=0,05$. The relationship pattern between the two variables is expressed by the regression equation $\ddot{Y}=a+b X 1=78.143+$ $0.397 \mathrm{X} 1$. This equation provides information that each change in one leadership unit will result in a change in work discipline of 0.397 with a constant 78.143.The results of a simple correlation analysis between principals' leadership on work discipline obtained ry 1 correlation coefficient of 0.369 this value gives the understanding that the relationship between the principal's leadership towards work discipline is quite high and positive, meaning that the better the headmaster's leadership is expected the higher the level of work discipline. Likewise, vice versa, the worse the leadership of the principal is, the lower the work discipline.

The contribution of the principal's leadership variable to work discipline can be known by squaring the acquisition of a simple correlation coefficient. The result of a simple correlation coefficient is 0.136 . Statistically this value gives the understanding that approximately $13.6 \%$ of the variation in discipline can be explained by the leadership of the principal. While $86.4 \%$ is influenced by other factors. This reinforces the theory described in the following chart:

Robbins (1991), says that "leadership is the ability to influence a group towards achievement (goal) ". The organization will run well if the leader has skills in his field, and each leader has different skills, such as technical, human and conceptual skills. While subordinates are a person or group of people who are members of an association or followers who are ready at any time to carry out orders or tasks that have been agreed upon to achieve the goal. In an organization, subordinates have a very strategic role, because the success or failure of a leader depends on these followers. Therefore, a leader is required to choose subordinates as carefully as possible.

Work discipline is determined by many factors and among these factors is the leadership of the principal. The organizational climate is real or $13.6 \%$ can improve work discipline. This means that the relationship between the principal's leadership variables on work discipline in accordance with the regression equation $\ddot{Y}=78.143+$ 


\section{$0.397 X 1$.}

\subsection{Interpretation of significant influences on work culture}

The descriptive results of the variable $(\mathrm{Y})$ are explained by the number of cases $(\mathrm{N})=77$ with an average of 128.45 and standard deviation $=16,386$. Descriptive results of variables $(\mathrm{X} 2)$ in the Descriptive Statistics table explain that there are a number of cases $(\mathrm{N})=77$ respondents; the mean is 128.90 and the standard deviation is 17.746 .

The results of the coefficient test, in this section constant value $=68,729$ and $\mathrm{B}$ value $=0,463$ and the price of $t$ count $=5,024$ and the significance level $=0,000$. From the coefficient table obtained the regression calculation equation $\ddot{Y}=a+b X 2=68,729+0,463 X 2$. Regression coefficient of 0.463 states that the better the work culture is predicted to improve work discipline. Conversely, if the work culture deteriorates, work discipline is also predicted to decline. So, this states the direction of predictions (linear). Information on the increase or decrease in work culture variables (X2) will result in an increase / decrease in work discipline variables (Y).

Table 2

Coefisien Corelation $\mathrm{X}_{2}$ Toward $\mathrm{Y}$

\begin{tabular}{lrrrrr}
\multirow{2}{*}{ Model } & \multicolumn{2}{c}{ Unstandardized Coefficients } & Standardized Coefficients & \multirow{2}{*}{ Sig. } \\
\cline { 2 - 4 } & $\mathrm{B}$ & Std. Error & Beta & & \\
\hline 1 & (Constant) & 68,729 & 11,999 & $5,728,000$ \\
\cline { 2 - 5 } X2 &, 463 &, 092 &, 502 & $5,024,000$
\end{tabular}

From the coefficient table obtained work culture variables and work discipline Sig. equal to 0,000 then compared with probability 0.05 it turns out that the probability value of 0.05 is greater than the probability value Sig. or $[0.05>0,000]$, then Ho is rejected and Ha is accepted. It is evident that there is a significant influence between work culture and work discipline.

Testing the second hypothesis concludes that there is a significant positive effect on work culture on work discipline indicated by $\mathrm{F}$ count $=25.240>$ Ftable $=3.120$ at a significant level $\alpha=0.05$. The relationship pattern between the two variables is expressed by the regression equation $\ddot{Y}=a+b X 2=68,729+0,463 X 2$. This equation provides information that any change in one work culture unit will result in changes in work discipline of 0.463 with a constant of 68.729 . From the regression equation obtained $\ddot{Y}=68,729+0,463 X 2$, then any increase in work culture score is followed by an increase in work discipline scores or it can be explained that the higher the work culture, the higher the work discipline.

The results of a simple regression analysis between leadership behavior and work discipline obtained the value of the ry 2 correlation coefficient of 0.502 . This value gives an understanding that the relationship between work culture and work discipline is very high and positive. The result of a simple correlation coefficient is 0.252 . Statistically this value gives an understanding that approximately $25.2 \%$ of the variation in work discipline can be explained by work culture. Whereas $74.8 \%$ is influenced by other factors.

Triguno (2000) argues that work culture is a philosophy that is based on a view of life as values that are traits, habits and driving forces, entrenched in the life of a community group or organization, then reflected in attitude to behavior, belief, ideals opinions and actions that manifest as work or work. Real work culture or $25.2 \%$ can improve work discipline. That is, if an assessment of the work culture with work discipline is carried out, then approximately $25.2 \%$ of the variations in the score pairs of the two variables will be distributed and follow the pattern of relationships between work culture variables and work discipline according to the regression equation $\ddot{\mathrm{Y}}=68,729+0,463 \mathrm{X} 2$.

4.3 Interpretation of Effects on Principal Leadership and Work Culture together on Work Discipline Test significance simultaneously (together)Based on the Model Table Summary that the magnitude of the relationship between leadership and work culture simultaneously (together) on work discipline calculated by the determinant coefficient is 0.509 or (Ryx $1, \mathrm{x} 2=0.509)$ this shows a strong influence. While simultaneous contributions or contributions of variables X1 and X2 to $\mathrm{Y}=\mathrm{R} 2 \times 100 \%$ or $0.509 \times 100 \%=50.9 \%$ while the remaining $49.1 \%$ is determined by other variables.

Table 3

Sumarry Coefisien Corelasi $\mathrm{X}_{1}, \mathrm{X}_{2}$ Toward $\mathrm{Y}$

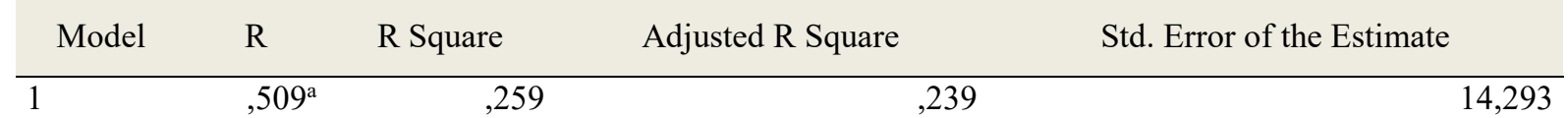

Then to find out the significant level of multiple correlation coefficients tested as a whole. The statistical hypothesis is formulated as follows

$\mathrm{Ha}: \mathrm{R}_{\mathrm{yx} 1, \mathrm{x} 2}=0$

Ho: $\mathrm{R}_{\mathrm{yx} 1, \mathrm{x} 2}>0$

Ha: Principal leadership and work culture have a significant influence on work discipline.

Ho: Principal leadership and work culture do not significantly influence work discipline. 
Test the significance of multiple correlations by comparing the probability value of 0.05 with the probability value Sig. on the basis of decision making as follows:

If the probability value of 0.05 is smaller or equal to the probability value of sig. $F_{\text {Change }}$ atau $[0,05 \leq \operatorname{sig}$. $\left.\mathrm{F}_{\text {Change }}\right]$,, then Ho is accepted and $\mathrm{Ha}$ is rejected, meaning is not significant.

If the probability value of 0.05 is greater or equal to the proletariat value of sig. $F_{\text {Change }}$ atau $\left[0,05 \geq \operatorname{sig}\right.$. $\left.F_{\text {Change }}\right]$, then $\mathrm{Ho}$ is rejected and $\mathrm{Ha}$ is accepted, meaning significant.

From the Model Summary table, the Rsquare value is 0.259 with a probability value (sig. FCange) $=0,000$. Because the sig value. FChange $<0.05$, then the decision is Ho rejected and Ha accepted. This means that principals' leadership and work culture have an effect on simultaneously and significantly on work discipline.

Hypothesis testing concludes that there is a very significant positive influence on principals' leadership and work culture together on work discipline indicated by Fcount $=12,946>$ Ftable $=3,120$ at a significant level $\alpha=$ 0,05 . The relationship pattern between the three variables is expressed by the multiple regression equation $\ddot{Y}=a$ $+\mathrm{bX} 1+\mathrm{bX} 2=61.759+0.116 \mathrm{X} 1+0.404 \mathrm{X} 2$. This equation provides information that each change in one headmaster's leadership score unit and one unit work culture score will result in changes in work discipline by 0.116 or 0.404 with a constant 61.759 .

The results of multiple regression analysis between principals' leadership and work culture together towards work discipline obtained a double correlation coefficient value of ry 12 of 0.509 . This value gives an understanding that the relationship between leadership and work culture together towards work discipline is very high and positive. The results of the analysis show that approximately $25.9 \%$ of the variation in work discipline can be explained by the leadership of the principal and the work culture together with the pattern of functional relations as indicated by the regression equation above.

The understanding of discipline according to Wagner and Holienbeck (2010) is as follows: "Discipline is performing a task with obedience and dedication. It can be expected only when a firm manager and subordinates agree on the specific behaviors that subordinate will perform ". Discipline is doing or carrying out a task with obedience and dedication. Discipline can be obtained only when a company manager and subordinates agree to behave specifically that the subordinates / subordinates will carry out. So, the discipline does a job in accordance with what has become a mutual agreement between managers and workers in this case the principal with the teacher.

Furthermore Cascio and Aguinis (2005) define discipline as, "Self discipline is committed, consistent, and dependable, can be relied on to deliver what has been agreed to, is punctual and conscientious". Self-discipline is a commitment, consistent and reliable to deliver what has been agreed upon, namely timely and meticulously. From some of the terms of the discipline that have been stated, there are several things that become the essence of discipline. The essence includes at least three things, namely: rules or norms, consistency and punishment.

When evaluating the leadership of the principal and work culture together towards work discipline, approximately $25.9 \%$ of the variations in the score pairs of the three variables will be distributed and follow the pattern of the relationship between the variables of Leadership and work culture together towards work discipline according to the regression equation $\ddot{Y}=61.759+0.116 \mathrm{X} 1+0.404 \mathrm{X} 2$.

\section{Conclussion and Suggestion :}

Conclussion :

Based on the results of the research and discussion presented, conclusions can be drawn as follows:

1. There is a significant influence on the principal's leadership towards work discipline. This implies that the work discipline can be improved through improving the leadership of the principal, the better the leadership of the principal in a school, the better the discipline of work in the school.

2. There is a significant influence on work culture towards work discipline. It can be interpreted that work discipline can be improved through improving work culture, the better the work culture, the better the work discipline at the school.

3. There is a significant influence on principals' leadership and work culture together on teacher work discipline. It can be interpreted that work discipline can be improved through improving the leadership of the principal and work culture, the better the leadership of the principal and work culture, the better the discipline of work at the school.This conclusion means that the low work discipline of teachers can be improved through improvements to the leadership of the principal and work culture.

\section{Suggestion}

Based on the conclusions of the results of the research, it can be stated several things related to the improvement of work discipline through improving the leadership of the principal and work culture, namely as follows:

1. Given the importance of the influence of the principal's leadership on teacher work discipline, the principal must pay attention to the appropriate leadership style in carrying out his duties. For example, the leadership style of elementary school principals in Minahasa should use situational leadership styles to create a comfortable and 
conducive work culture.

2. Work culture also has an influence on teacher work discipline. Therefore, it is expected for school leaders to be able to make policies and implement them so that schools become conducive so that the teacher's work discipline becomes better.

3. It is hoped that this research can be used as input as a foothold in conducting further research in order to strengthen the conception of this research and be able to gain a basis for improvement in the world of further education. Of course by expanding the population and samples so that the results of research can be used by a wider audience.

\section{References}

Amstrong, Michael. (2006). Human Resource Management Practice. Cambridge University Press. and Factors Affecting it, Rineka Cipta.Jakarta

Arianto, D. A. N. (2013). Pengaruh kedisiplinan, lingkungan kerja dan budaya kerja terhadap kinerja tenaga pengajar. Jurnal Economia, 9(2), 191-200.

Casio F. Wayne, Herman Aguinis. (2005). Aplied Psychology in Human Resource Management. New Jersey.

Davis Gordon. 1991. Basic Framework of Management Information Systems. Section 1 PT. Reader Binamas Pressindo. Jakarta.

Djamal, Z. 2005. Certification and License of Professional Lecturer. Journal of education, Bandung:

Gibson, James L.1994. Organization Behavior,Structure and Process, (Nunuk Ardiani Translation, Bina Aksara, Jakarta).

Ginnet, dan Curphy. (2010). Leadership: Enhancing the Lessons of Experiencie, 7th ed. (terjemahan). Jakarta: Salemba Humanika.

Handayani, T., \& Rasyid, A. A. (2015). Pengaruh kepemimpinan kepala sekolah, motivasi guru, dan budaya organisasi terhadap kinerja guru SMA negeri Wonosobo. Jurnal Akuntabilitas Manajemen Pendidikan, 3(2), 264-277.

Hasan, Iqbal. 2010. Analisis Data Penelitian Dengan Statistik. Jakarta: Bumi Aksara.

Hunt, Gilbert H. 1999. Professional Teacher Performance Master's Perception Relationship on Leadership Head, Gramedia, Jakarta

Kambey, Daniel C. (1995). Didaktik Metodik. Manado: Tri Ganesha Nusantara.

Kambey, Daniel C. (2010). Landasan Teori Administrasi/Manajemen. Manado: Tri Ganesha Nusantara.

Kanfer Ruth, Gilad Chen, Robert D. Prithcard. (2008). Work Motivations, Past, Present, and Future. New York: Routledge.

Kemendikti-Unima, 2011. Teacher Professionalism: Teacher Profession Training Material, Rayon 27 Unima, Tondano

Kepmenpan No. 25 / Kep / M.Pan/4/2002, on Guidelines for the Development of State Apparatus Culture Work

Kewo, C. L., \& Afiah, N. N. (2017). Does Quality of Financial Statement Affected by Internal Control System and Internal Audit?. International Journal of Economics and Financial Issues, 7(2), 568-573.

Koentjaraningrat. (2007). Manusia dan Kebudayaan Di Indonesia. Jakarta: Djambatan

Komariah, Aan dan Cepi Triatna. (2006). Visionary Leadership Menuju Sekolah Efektif. Bumi Aksara. Bandung.

Madjid, A, E. 2008, Learning Planning, Developing Teachers Competency Stadards. PT Remaja Rosdakarya, Bandung

Mantja, Willem. (2005). Manajemen Pendidikan dan Supervisi Pendidikan. Kumpulan Karya Tulis Terpublikasi. Malang : Wineka Media.

Modern Office Administration. 10th Print Publisher Nur Cahaya, Yogyakarta.

Mulyasa, E. (2011). Manajemen Pendidikan Karakter. Bumi Aksara. Jakarta

Ndraha, Taliziduhu. (1997). Budaya Organisasi. Rineka Cipta. Jakarta.

Nugroho, Yohanes Anton. (2011). It's Easy... Olah Data dengan SPSS. Yogyakarta: Skripta Media Creative.

Rawis, Joulanda A.M. 2016. Supervivi Klinis, Reference Book, LP2AI - Unima, Tondano

Reigeluth, Charles M \& Robert J. Garfinkle, 1994, Systemic change in Education, Educational Technology Publications Englewood Cliffs, New Jersey

Riduwan. (2011). Cara Mudah Belajar SPSS versi 17.0 dan Aplikasi Statistik Penelitian.Bandung: Alfabeta.

Robbins, S., and Timothy A. J. 2008. Perilakudan Organization Management (Translation), Gramedia, Jakarta

Robbins, Stephen dan Marry Coulter. (1991). Manajemen (edisi Indonesia). Jakarta: Gramedia.

Robert R. Katz, in Moenir. 2008. Public Service Management in Indonesia Bumi Aksara, Jakarta:

Setiyati, S. (2014). Pengaruh kepemimpinan kepala sekolah, motivasi Kerja, dan budaya sekolah terhadap kinerja guru. Jurnal Pendidikan Teknologi dan Kejuruan, 22(2), 200-206.

Sudjana, Nana, 1983. Assessment of Teaching and Learning Process Results, PT Remaja Rosdakarya, Bandung

Syafaruddin. (2005). Manajemen Mutu Terpadu dalam Pendidikan. Konsep, Startegi dan Aplikasinya. Jakarta: Grasindo.

Taniredja Tukiran dan Hidayati Mustafidah. (2011). Penelitian Kuantitatif(Sebuah Pengantar). Bandung: Alfabeta. 
Triguno. (2000). Budaya Kerja. PT. Golden Terayun Press. Jakarta.

Umar, Husein, 2004. Research Method of Administration Science, PT. Gramedia Pustaka Utama, Jakarta. Wagner and Holienbeck. (2010). Organizational Behavior. New York: Routledge.

Yulk Gary. (2002). Leadership in Organizations. New Jersey: Prentice-Hall.Inc. 